\title{
THE RELATION OF PARENTS' BEHAVIOUR ON DENTAL HEALTH TOWARD THEIR DEAF CHILDREN'S ORAL HEALTH STATUS: CASE STUDY IN SDLB ABC SWADAYA KALIWUNGU KENDAL
}

\author{
$\operatorname{Sadimin}^{\bowtie 1}$, Endah Aryati Eko Ningtyas ${ }^{2}$, Yodong $^{3}$
}

\begin{abstract}
ABSTRAK
Pertumbuhan dan perkembangan anak tunarungu sering menimbulkan masalah kesehatan, salah satunya adalah masalah kesehatan gigi dan mulut. Faktor yang mempengaruhi tingkat kesehatan gigi dan mulut adalah pengetahuan, sikap dan tindakan. Kesehatan gigi anak tunarungu dipengaruhi oleh perilaku orang tua terhadap pemeliharaan kesehatan gigi dan mulut. Tujuan penelitian ini untuk mendeskripsikan hubungan pengetahuan, sikap dan tindakan orang tua tentang kesehatan gigi dan mulut terhadap status kesehatan gigi dan mulut anak tunarungu.

Metode penelitian adalah observasional analitik, dengan pendekatan penelitiannya adalah cross sectional. Jumlah sampel pada penelitian ini yaitu sebanyak 30 orang dengan tehnik pengambilan sampel secara total sampling. Analisis data dilakukan dengan analisis univariat, analisis bivariat uji chi square dan analisis multivariate uji regresi logistik.

Hasil uji statistik menunjukkan pengetahuan, sikap dan tindakan orang tua tentang kesehatan gigi dan mulut mempunyai hubungan yang bermakna dengan kesehatan gigi dan mulut (DMF-T) anak tunarungu, dengan nilai $p$-value 0,003 ( $p<0,05)$. Variabel yang paling berhubungan dengan status kesehatan gigi dan mulut (DMF-T) pada anak tunarungu adalah sikap dimana $p=0,002$. Kesimpulan penelitian ini adalah pengetahuan, sikap dan tindakan orang tua tentang kesehatan gigi dan mulut berhubungan dengan status kesehatan gigi dan mulut (DMF-T) anak tunarungu. Sikap merupakan variabel yang paling berhubungan dengan status kesehatan gigi dan mulut (DMF-T).
\end{abstract}

Kata kunci : Pengetahuan, sikap, tindakan kesehatan gigi dan mulut

\begin{abstract}
The Growth and the development of deaf children often cause the health problems, one of the problem is oral health. Factors that affect the level of oral health are knowledge, attitude and action. The deaf children dental health is influenced by the parents' behavior to maintenance of oral health. The purpose of this research was to describe the relation of knowledge, attitudes and actions of parents about dental and oral health on dental health status of the deaf children.

The research method is observational analytic, with cross sectional research approach. The samples in this research was 30 people, it was total sampling for sampling technique. It was univariate analysis, bivariate analysis (chi square) and multivariate analysis (logistic regression) for data analysis.

The results of statistical tests showed that parent's knowledge, attitudes and actions about dental and oral health have a significant relation with dental and mouth health status (DMF-T) of the deaf children, with $p$ value 0,003 ( $p<0.05)$. The most related variable with dental and mouth health status (DMF-T) in deaf children is the attitude was $p=0.002$. The conclusion of this research is parent's knowledge, attitudes and actions about oral and dental health related to dental and mouth health status (DMF-T) of the deaf children. Attitude is the most related variable to dental and mouth health status (DMF-T).
\end{abstract}

Keywords : Knowledge, attitude, action of dental and mouth health

\footnotetext{
${ }^{1,2,3)}$ Jurusan Keperawatan Gigi Poltekkes Kemenkes Semarang

$\bowtie$ : sadimingolden@gmail.com
} 


\section{PENDAHULUAN}

Kesehatan gigi merupakan bagian integral dari kesehatan secara keseluruhan yang dapat mempengaruhi kualitas hidup. Prevalensi karies gigi dan penyakit periodontal tinggi di masyarakat dan hasil penelitian menunjukkan karies gigi mempunyai dampak yang luas, yaitu gangguan pada kualitas hidup antara lain keterbatasan fungsi, disabilitas fisik, ketidaknyamanan psikis dan disability (Kementrian Kesehatan RI, 2012).

Karies gigi adalah merupakan suatu proses demineralisasi yang progresif pada jaringan keras permukaan mahkota dan akar gigi yang dapat dicegah. Di Indonesia penyakit karies gigi serta penyakit gigi dan mulut masih banyak diderita oleh anak-anak. Menurut Data Kementerian Kesehatan Tahun 2010 prevalensi karies di Indonesia mencapai $60 \%$ - 80\%. Hal ini disebabkan oleh faktor-faktor antara lain distribusi penduduk, faktor lingkungan, faktor perilaku dan faktor pelayanan kesehatan yang berbeda pada masyarakat Indonesia (Kemenkes, 2011).

Pengetahuan dan sikap akan menjadi landasan terhadap pembentukan moral remaja sehingga dalam diri seseorang individu idealnya ada keselarasan yang terjadi antara pengetahuan dan sikap, dimana sikap terbentuk setelah terjadi proses tahu terlebih dahulu (Suryani dkk, 2009).

Anak Berkebutuhan Khusus (ABK) yaitu anak dengan keterbatasan fisik dan mental yang memiliki keterbatasan kondisi fisik perkembangan, tingkah laku atau emosi. Hal ini menyebabkan terjadinya gangguan fungsi fisiologis, psikologis atau struktur anatomi berkurang atau hilang, sehingga tidak dapat menjalankan aktifitas kehidupan sehari-hari secara normal yang mengakibatkan perubahan dalam alam pikiran, alam perasaan dan perbuatan.

Masalah sosial pada anak berkebutuhan khusus memengaruhi kebutuhan pendidikan anak-anak tersebut sehingga memiliki pengetahuan yang masih kurang khususnya pengetahuan di bidang kesehatan. Pengetahuan tentang cara memelihara kesehatan gigi yang rendah mendukung tingginya angka karies pada anak berkebutuhan khusus. Oleh karena itu, anak berkebutuhan khusus memerlukan jenis pelayanan kesehatan lebih dari yang dibutuhkan oleh anak normal secara umum.

Tujuan penelitian ingin mengetahui hubungan pengetahuan, sikap dan tindakan orang tua tentang kesehatan gigi dan mulut terhadap status kesehatan gigi dalam hal ini karies gigi pada anak tunarungu di SDLB ABC Swadaya Kecamatan Kaliwungu Kendal.

\section{METODE PENELITIAN}

Jenis penelitian merupakan penelitian observasional analitik dengan study regresi. Pengambilan data dilakukan secara cross sectional. Populasi penelitian dilakukan pada siswa tunarunga SDLB ABC Swadaya Kaliwungu Kendal sebanyak 30 anak. Pengambilan sampel dilakukan secara total sampling. Untuk melihat hubungan variabel bebas terhadap variabel terikat dilakukan uji Regresi Logistik, yang didahului dengan uji Chi Square.

\section{HASIL DAN PEMBAHASAN}

\section{Hasil Analisis Univariat}

Tabel 1. Distribusi Frekuensi Kuesioner Pengetahuan Orang Tua Tentang Kesehatan Gigi dan Mulut

\begin{tabular}{lcc}
\hline \multicolumn{1}{c}{ Kriteria } & $\mathrm{n}$ (Jumlah) & $\%$ \\
\hline Baik & 24 & 80 \\
Sedang & 6 & 20 \\
Buruk & 0 & 0 \\
\hline Jumlah & 30 & 100 \\
\hline
\end{tabular}

Berdasarkan tabel diatas diketahui bahwa sebagian besar responden telah memiliki pengetahuan yang baik tentang kesehatan gigi dan mulut yaitu sebesar $80 \%$. 
Tabel 2. Distribusi Frekuensi Kuesioner Sikap Orang Tua Tentang Pemeliharaan Kesehatan Gigi dan Mulut

\begin{tabular}{ccc}
\hline Kriteria & n (Jumlah) & $\%$ \\
\hline Sangat Baik & 16 & 53 \\
Baik & 11 & 37 \\
Cukup Baik & 3 & 10 \\
Buruk & 0 & 0 \\
Sangat Buruk & 0 & 0 \\
\hline Jumlah & 30 & 100 \\
\hline
\end{tabular}

Berdasarkan tabel diatas diketahui bahwa sebagian besar responden memiliki sikap yang sangat baik tentang kesehatan gigi dan mulut yaitu sebesar $53 \%$.

Tabel 3. Distribusi Frekuensi Kuesioner Tindakan Orang Tua Tentang Pemeliharaan Kesehatan Gigi dan Mulut

\begin{tabular}{ccc}
\hline Kriteria & n (Jumlah) & $\%$ \\
\hline Baik & 21 & 70 \\
Kurang & 9 & 30 \\
\hline Jumlah & 30 & 100 \\
\hline
\end{tabular}

Berdasarkan Tabel diatas $70 \%$ responden melakukan tindakan pemeliharaan kesehatan gigi dan mulut.

Tabel 4. Distribusi Frekuensi Hasil Pemeriksaan Kesehatan Gigi dan Mulut (DMF-T) pada Anak Tunarungu

\begin{tabular}{ccc}
\hline Kriteria & $\mathrm{n}$ (jumlah) & $\%$ \\
\hline Sangat Rendah & 22 & 73 \\
Rendah & 8 & 27 \\
Sedang & 0 & 0 \\
Tinggi & 0 & 0 \\
Sangat Tinggi & 0 & 0 \\
\hline Jumlah & 30 & 100 \\
\hline
\end{tabular}

Berdasarkan tabel diatas $73 \%$ responden mempunyai status kesehatan gigi dan mulut dalam hal ini DMF-T yang sangat rendah.

\section{Hasil Analisis Bivariat}

Pelaksanaan uji korelasi dilakukan dengan uji chi square a. Hubungan pengetahuan dengan DMF-T Tabel 5. Hubungan Pengetahuan Orang Tua Tentang Kesehatan Gigi dan Mulut dengan DMF-T Anak Tunarungu

\begin{tabular}{lcccc}
\hline \multicolumn{1}{c}{ DMF-T } & $\begin{array}{c}\text { Sangat } \\
\text { rendah } \\
\text { Pengetahuan }\end{array}$ & Rendah & Total & p-value \\
\hline Baik & 20 & 4 & 24 & 0,013 \\
Sedang & 2 & 4 & 4 & $(\mathrm{n})$ \\
\hline \multicolumn{1}{c}{ Total } & 22 & 8 & 30 & \\
\hline
\end{tabular}

Berdasarkan tabel diatas diketahui bahwa pada reponden paling banyak ditemukan DMF-T sangat rendah dengan pengetahuan baik yaitu sebesar 20 responden. Hasil uji statistik menunjukkan nilai $\mathrm{p}$-value $0,013(p<0,05)$ sehingga Ho ditolak dan $\mathrm{Ha}$ diterima, dan dapat disimpulkan bahwa ada hubungan yang signifikan antara pengetahuan orang tua tentang kesehatan gigi dan mulut dengan DMF-T anak tunarungu.

\section{b. Hubungan Sikap dengan DMF-T}

Tabel 6. Hubungan Sikap Orang Tua Tentang Kesehatan Gigi dan Mulut dengan DMF-T Anak Tunarungu

\begin{tabular}{lcccc}
\multicolumn{5}{c}{ Anak Tunarungu } \\
\hline DMF-T & $\begin{array}{l}\text { Sangat } \\
\text { rendah } \\
\text { Sikap }\end{array}$ & Rendah & Total & p-value \\
Sangat Baik & 15 & 1 & 16 & \\
Baik & 7 & 4 & 11 & 0,002 \\
Cukup Baik & 0 & 3 & 3 & \\
\hline \multicolumn{1}{c}{ Total } & 22 & 8 & 30 & \\
\hline
\end{tabular}

Berdasarkan tabel diatas diketahui bahwa pada reponden paling banyak ditemukan DMF-T sangat rendah dengan sikap sangat baik yaitu sebesar 15 responden. Hasil uji statistik menunjukkan nilai p-value $0,002(p<0,05)$ sehingga Ho ditolak dan Ha diterima, dan dapat disimpulkan bahwa ada hubungan yang signifikan antara sikap orang tua tentang kesehatan gigi dan mulut dengan DMF-T anak tunarungu. 
c. Hubungan Tindakan dengan DMF-T

Tabel 7. Hubungan Tindakan Orang Tua Tentang Kesehatan Gigi dan Mulut dengan DMF-T

Anak Tunarungu

\begin{tabular}{lcccc}
\hline DMF-T & $\begin{array}{c}\text { Sangat } \\
\text { rendah } \\
\text { Tindakan }\end{array}$ & Rendah & Total & p-value \\
\hline Dilakukan & 19 & 2 & 21 & 0,001 \\
Tidak Dilakukan & 3 & 6 & 9 & \\
\hline \multicolumn{1}{c}{ Total } & 22 & 8 & 30 & \\
\hline
\end{tabular}

Berdasarkan tabel diatas diketahui bahwa pada reponden paling banyak ditemukan DMF-T sangat rendah dengan orang tua yang melakukan tindakan pemeliharaan kesehatan gigi dan mulut yaitu sebesar 19 responden. Hasil uji statistik menunjukkan nilai p-value $0,001 \quad(p<0,05)$ sehingga Ho ditolak dan Ha diterima, dan dapat disimpulkan bahwa ada hubungan yang signifikan antara tindakan orang tua tentang kesehatan gigi dan mulut dengan DMF-T anak tunarungu.

\section{Hasil Analisis Multivariat}

Analisis multivariat untuk mencari hubungan masing-masing variabel bebas secara bersama-sama dengan variabel terikat serta mencari manakah variabel bebas yang paling berpengaruh dengan variabel terikat dengan uji analisis regresi logistik.

Hasil analisa menunjukkan baik variabel pengetahuan, sikap dan tindakan berhubungan dengan status kesehatan gigi dan mulut (DMF-T) dengan nilai $p<0,05$. Kemudian dilakukan uji multivariat dengan analisis regresi logistik dengan hasil sebagai berikut :

Tabel 8. Hasil Uji Analisis Regresi Logistik

\begin{tabular}{lcc}
\hline \multicolumn{1}{c}{ Variabel } & Signifikansi & OR \\
\hline Pengetahuan & 0,067 & 20.710 \\
Sikap & 0,043 & 10.444 \\
Tindakan & 0,183 & 5.005 \\
\hline
\end{tabular}

Berdasarkan tabel diatas, variabel yang paling berpengaruh dengan DMF-T adalah sikap dimana didapatkan nilai $p=$ 0,043 dan OR 10.444 yang artinya responden dengan sikap pemeliharaan kesehatan gigi dan mulut yang sangat buruk beresiko mengalami kerusakan gigi sebesar 10.444 kali dibandingkan dengan responden dengan sikap pemeliharaan kesehatan gigi dan mulut yang sangat baik.

Berdasarkan Tabel 1 diketahui bahwa $80 \%$ responden mempunyai pengetahuan yang baik tentang kesehatan gigi dan mulut, sehingga diketahui bahwa sebagian besar orang tua yang memiliki pengetahuan baik tentang kesehatan gigi dan mulut, juga memiliki anak dengan DMF-T yang sangat rendah. Dalam penelitian ini tidak ada orang tua yang berpengetahuan buruk tentang kesehatan gigi dan mulut, hal ini dikarenakan adanya kegiatan UKGS yang rutin dilakukan dan melibatkan oleh orang tua anak dalam pelaksanaan kegiatan UKGS.

Berdasarkan hasil analisis kuesioner diketahui bahwa sebagian besar responden masih belum mengetahui jenis sikat gigi yang baik untuk membersihkan gigi dan mulut serta waktu yang tepat untuk mengganti sikat gigi. Meskipun telah mendapatkan pengetahuan tentang kesehatan gigi dan mulut dalam kegiatan UKGS di SDLB ABC Swadaya, namun sejalan dengan waktu pengetahuan tantang kesehatan gigi dan mulut akan berkurang, bahkan dilupakan ketika tidak diimplementasikan dalam kehidupan sehari-hari, hal ini sesuai dengan pendapat Notoatmodjo (2007) bahwa belajar adalah usaha untuk menguasai segala sesuatu dengan menghafal, mengingat dan mereproduksi, yang menyatakan bahwa struktur kognitif, psikomotor dapat terjadi jejak-jejak konsep yang tesususn secara berjenjang, yang tergantung representasi masa lalu pada struktur kognitif. Informasi baru sewaktu-waktu dapat dipanggil sebagai satu kesatuan yang berdiri sendiri, tetapi lama-kelamaan terjadi proses peleburan sehingga informasi itu sering dilupakan.

Hasil uji statistik diperoleh $p$-value 0,013 yang berarti ada hubungan yang bermakna antara pengetahuan dengan kesehatan gigi dan mulut. Hal itu didukung oleh teori yang dikemukakan oleh Putri dkk 
(2013) yang menyebutkan bahwa kesehatan gigi dan mulut seseorang tergantung dari keadaan situasi yang ada dalam mulut dan tingkat kerajinan untuk membersihkan mulut. Kesehatan gigi dan mulut dipengaruhi oleh beberapa faktor diantaranya adalah faktor internal dan eksternal. Adapun faktor eksternal yaitu perilaku (pengetahuan).

Hasil penelitian menunjukkan hal yang sama dengan penelitan sebelumnya yang dilakukan oleh Warsini (2010) dan Asri dkk (2015) yang menyatakan ada hubungan antara pengetahuan tentang kesehatan gigi dan mulut dengan status kesehatan gigi dan mulut (DMF-T). Selain itu dari hasil analisis multi varian bahwa pengetahuan merupakan variabel yang berhubungan dengan status kesehatan gigi dan mulut (DMF-T) dimana didapatkan nilai $\mathrm{p}=0,013$

Berdasarkan Tabel 2 diketahui bahwa sebagian besar responden memiliki sikap yang sangat baik dan ditemukan status DMF$\mathrm{T}$ sangat rendah dengan sikap sangat baik (15 responden). Adapun responden dengan DMF-T rendah dengan sikap cukup baik yaitu sebanyak 3 responden. Berdasarkan analisis kuesioner diketahui bahwa sebagian besar responden belum mempunyai sikap yang baik dalam hal penggantian sikat gigi yang baik dan benar, kesadaran untuk memeriksakan gigi secara rutin/berkala tanpa menunggu rasa sakit timbul terlebih dahulu serta waktu yang tepat untuk menyikat gigi. Sesuai dengan pendapat Notoatmodjo (2007) bahwa manifestasi sikap tidak dapat langsung terlihat tetapi hanya dapat ditafsirkan terlebih dahulu dari perilaku yang tertutup, secara nyata sikap menunjukkan konotasi adanya kesesuaian reaksi terhadap stimulus tertentu yang dalam kehidupan sehari-hari merupakan reaksi yang bersifat emosional terhadap stimulus sosial. Oleh karena itu dari responden yang belum mempunyai sikap yang baik dalam pemeliharaan kesehatan gigi, mereka juga mempunyai anak dengan DMF-T yang rendah hal ini bias disebabkan karena implementasi sikap yang tidak mengganti sikat gigi dengan benar, tidak memeriksakan gigi secara berkala serta masih banyak responden yang hanya menyikat gigi ketika mandi pagi dan sore.

Hasil uji statistik diperoleh p-value 0,002 yang berarti ada hubungan yang bermakna anatara sikap dengan DMF-T. Hal tersebut didukung oleh teori yang dikemukakan oleh Rahayu dkk (2014) yang menyebutkan bahwa salah satu fator utama yang mempengaruhi gigi dan mulut penduduk dinegara berkembang adalah sikap dan perilaku. Hasil penelitian menunjukan hal yang sama dengan penelitian sebelumnya yang dilakukan oleh Sariningrum (2009) yang menyatakan ada hubungan antara sikap ibu tentang kesehatan gigi dan mulut dengan tingkat kejadian karies.

Hasil analisis multivariat diketahui bahwa sikap merupakan variabel yang paling berpengaruh dengan variabel status kesehatan gigi dan mulut (DMF-T) dimana dihasilkan nilai $\mathrm{p}=0,043$ dan OR 10.444 yang artinya responden dengan sikap pemeliharaan kesehatan gigi dan mulut yang sangat buruk beresiko mengalami kerusakan gigi sebesar 10.444 kali dibandingkan dengan responden dengan sikap pemeliharaan kesehatan gigi dan mulut yang sangat baik.

Berdasarkan Tabel 3 diketahui bahwa sebagian responden memiliki tindakan yang baik dan responden yang melakukan tindakan pemeliharaan kesehatan gigi dan mulut memiliki DMF-T yang sangat rendah. Hasil uji statistik diperoleh $\mathrm{p}$-value $=0,001$ yang berarti bahwa ada hubungan yang bermakna antara tindakan orang tua tentang kesehatan gigi dan mulut terhadap status kesehatan gigi dan mulut. Hal tersebut didukung oleh teori yang kemukakan oleh Suresh et al (2010) dimana peran orang tua terutama seorang Ibu terhadap bagaimana menjaga kesehatan gigi dan mulut sangat penting dalam mendasari terbentuknya perilaku yang mendukung kebersihan gigi dan mulut anak sehingga kesehatan gigi dan mulut anak dapat menjadi baik.

Berdasarkan analisis kuesioner diketahui bahwa masih banyak responden 
yang menggunakan tusuk gigi untuk membersihkan gigi dan menyikat gigi hanya ketika mandi pagi dan sore, dalam hal ini masih banyak responden yang belum mempraktekkan apa yang telah mereka ketahui, bahwa menyikat gigi yang tepat adalah setelah sarapan dan sebelum tidur. Sesuai dengan pendapat Budiharto (2013) dimana tindakan memiliki 4 tingkatan yaitu persepsi, respon terpimpin, mekanisme dan adopsi. Dalam hal ini tindakan sebagian responden masih dalam tingkat yang pertama yaitu persepsi dimana responden sebatas mengenal, memilih berbagai obyek sehubungan dengan tindakan yang akan diambil.

Hasil penelitian menunjukkan hal yang sama dengan penelitan sebelumnya yang dilakukan oleh Warsini (2010) dan Asri dkk (2015) yang menyatakan bahwa ada hubungan antara tindakan orang tua tentang kesehatan gigi dan mulut terhadap status kesehatan gigi dan mulut (DMF-T). Notoatmodjo (2010) berpendapat bahwa stimulus atau rangsangan terdiri dari empat unsur pokok yakni sakit dan penyakit, sistem pelayanan dan lingkungan. Tindakan atau perilaku kesehatan terjadi setelah seseorang mengetahui stimulus kesehatan kemudian mengadakan penilaian terhadap yang diketahui dan memberikan respon batin dalam bentuk sikap. Proses selanjutnya diharapkan subyek akan melaksanakan apa yang diketahui atau disikapinya. Pengetahuan dan sikap merupakan factor yang sangat penting untuk terbentuknya praktek. Secara terperinci praktek manusia sebenarnya merupakan refleksi dari berbagai gejala kejiwaan seperti pengetahuan, dukungan, fasilitas, keinginan, kehendak, minat, motivasi dan persepsi.

\section{KESIMPULAN}

1. Pengetahuan orang tua tentang kesehatan gigi dan mulut pada anak tunarungu sebagian besar dalam kategori baik $(80 \%)$
2. Sikap orang tua tentang kesehatan gigi dan mulut pada anak tunarungu sebagian besar dalam kategori sangat baik (53\%)

3. Tindakan orang tua dalam pemeliharaan kesehatan gigi dan mulut pada anak tunarungu sebagian besar dalam kategori baik $(70 \%)$.

4. Hasil pemeriksaan kesehatan gigi (DMF$\mathrm{T}$ ) pada anak tunarungu sebagian besar dalam kategori sangat rendah $(73 \%)$.

5. Pengetahuan, sikap dan tindakan orang tua tentang kesehatan gigi dan mulut berhubungan dengan status kesehatan gigi dan mulut (DMF-T), sikap merupakan variabel yang paling berhubungan dengan status kesehatan gigi dan mulut (DMF-T)

\section{SARAN}

Berdasarkan hasil penelitian maka disarankan kepada orang tua untuk meningkatkan pengetahuan, sikap dan tindakan tentang kesehatan gigi dan mulut, pahami dan implementasikan hal-hal yang telah diketahui oleh orang tentang pemeliharaan kesehatan gigi dan mulut.

Kepada pihak sekolah disarankan untuk melakukan sikat gigi massal secara periodik dan terjadwal, sehingga kesehatan gigi anak lebih terjaga dan terkontrol. Membentuk tim UKS yang lebih solid dan mengadakan penyuluhan tentang kesehatan gigi dari guru UKS ke murid yang didampingi orang tua secara teratur dan terjadwal dengan baik.

\section{DAFTAR PUSTAKA}

Arikunto, S., 2010, Prosedur Penelitian Suatu Pendekatan Praktik, Rineka Cipta, Jakarta.

2014, Metodologi Penelitian Kesehatan Dan Kedokteran, Jakarta, Bursa Ilmu.

Bahri, S., 2010, Guru dan Anak Didik Dalam Interaksi Edukatif Suatu Pendekatan 
teoritis Psikologis, Rineka Cipta, Jakarta.

Budiharto, 2008, Pengantar Ilmu Perilaku Kesehatan Dan Pendidikan Kesehatan Gigi, EGC, Jakarta.

2013, Pengantar ilmu perilaku kesehatan dan pendidikan kesehatan gigi, Edisi revisi, EGC, Jakarta.

Delphie, B., 2007, Pembelajaran Anak Berkebutuhan khusus, Adi Tama, Bandung.

Gita, J., Tulangow, Damajanty, H., Parengkuan, W.G., 2015, Gambaran Status Karies Pada Anak Berkebutuhan Khusus di SLB YPAC Manado, Jurnal e-GiGi (eG), Volume 3.

Irwanto, Kasim dan Rahmi, 2010, Analisis Situasi Penyandang Disabilitas di Indonesia Pusat Kajian Disabilitas, Jurnal FISIP, Jakarta.

Mustika, M.D., (2014), Insidensi Karies Gigi Pada Anak Usia Pra Sekolah di TK Merah Meranggi Marta Pura, Dentino Jurnal Kedokteran Gigi, Vol 2 No 2.

Kemenkes, RI, 2011a, Karies Gigi Menempeti Peringkat ke Enam Sebagai Penyakit yang paling Banyak di Derita Masyarakat Indonesia, www.beritasatu.com

/kesehatan/140888-karies-gigimasalah-kesehatanserius-diIndonesia.

2011b, Pedoman Pelayanan Kesehatan Anak di Sekolah Luar Biasa (SLB), Direktorat Bina Kesehatan Anak Kementrian Kesehatan RI.

2013, Laporan Nasional Riset Kesehatan Dasar (RISKESDAS),
Badan Penelitian dan Pengembangan Kesehatan Republik Indonesia.

Mangunsong, F., 2011, Psikologi dan Pendidikan Anak Berkebutuhan Khusus, Jilid II, LPSP3 UI, Jakarta.

Maria V.A.R., Ade I.A.K., Muhammad D.F., 2014, Hubungan Pengetahuan Kesehatan Gigi dengan Kondisi Oral Hygiene Anak Tunarungu Usia Sekolah, Medali Jurnal, Volume 2 Edisi 1, Media Dental Intelektual.

Mohammad T.I., 2013, Pendidikan Inklusif konsep dan aplikasi, PT Aruzz Media, Jogjakarta.

Notoatmodjo, 2007, Domain Perilaku.Dalam Promosi Kesehatan dan Ilmu Perilaku, Rineka Cipta, Jakarta. , 2007, Kesehatan Masyarakat : Ilmu dan Seni, Rineka Cipta, Jakarta.

2010, Promosi Kesehatan Teori dan Aplikai, Edisi Revisi, Rineka Cipta, Jakarta.

, 2012, Metodologi Penelitian Kesehatan, Jakarta, Rineka Cipta.

Purwanti, 2011, Manajemen Pembelajaran PAI Bagi Anak Berkebutuhan Khusus (Studi di SDLB Negeri Salatiga), Jurnal Fakultas Tarbiyah, IAIN Walisongo Semarang.

Putri, M.H., Herijulianti, E. dan Nurjannah, N., 2013, Ilmu Pencegahan Penyakit Jaringan Keras dan Jaringan Pendukung Gigi, EGC, Jakarta.

Silvia, A. dan Endang, N.R., 2014, Hubungan Frekuensi Menyikat Gigi Dengan Tingkat Kebersihan Gigi Dan Mulut Anak Sekolah Dasar Negeri di Kecamatan Palaran Kotamadya 
Samarinda Provinsi Kalimantan Timur, Dental jurnal, Vol 38 P 8890.

Suresh, B.S., Ravishankar, T.L., Chaitra, T.R., Mohapatra, A.K. dan Gupta, V., 2010, Mother Knowledge about pre scool Child's oral Health, India: Journal of Indian Society of Pedodontics and Preventive Dentistry.

Suratri, M.A.L., Sintawati, F. dan Andayasari, L., 2014, Pengetahuan, Sikap dan Perilaku Orang tua tentang Kesehatan Gigi dan Mulut Pada Anak Usia Taman KanakKanak di Propinsi DIY dan Banten 2014, Badan Litbang, Jakarta, e.journal.litbang.depkes.go.id.

Sumawinata, N., 2010, Senara Istilah Kedokteran Gigi, EGC, Jakarta.

Sholichah, I., 2014, Alat Peraga Untuk Pelajar Tunarungu, Media Guru, Jakarta.

Widayati, N., 2014, Faktor-Faktor yang Berhubungan Dengan Karies Gigi Pada Anak, UNAIR Jurnal, Jurnal Berkala Epidemiologi. Vol 2. No. 2.

Widiyanto, T.P., 2009, Menggapai Prestasi Di Telaga Sunyi-Dinamika Pendidikan Kaum Tunarungu, Universitas Sanata Dharma.

Winarsih, M., 2007, Intervensi Dini Bagi Anak Tunarungu dalam Pemerolehan Bahasa, Departemen Pendidikan dan Kebudayaan, Direktorat Jenderal Pendidikan Tinggi, Direktorat Ketenagaan. 